\title{
SACRAMENTAL REALISM OF CHESTERTON AND LEWIS
}

PAVOL HRABOVECKÝ

\begin{abstract}
The aim of this study is to present G. K. Chesterton's and C. S. Lewis's understanding of sacramental realism and its possible adoption in pre-evangelisation. It is demonstrated that G. K. Chesterton's works influenced C.S Lewis's conversion, his Christian literary thinking, and his apologetics. Both Chesterton and Lewis offered sacramental perceptions of the world, available through the baptism of imagination. In their works, imagination helps reason to expand and recognise the supernatural in the natural. Therefore, imagination is an essential part of their apologetics of Christianity, which still appeals to contemporary man. In this way, new imaginative apologetics can serve as a suitable preparation for the proclamation of the Gospel today.
\end{abstract}

Keywords

C. S. Lewis; G. K. Chesterton; Pre-evangelisation; New Apologetics; Symbol; Imagination

DOI: $10.14712 / 23363398.2021 .7$

$\mathrm{T}$

wo Englishmen, two writers, two converts, two apologists who changed their times and influenced the view of Christianity among their contemporaries. Without exaggeration, G. K. Chesterton and C. S. Lewis could be described in such a way. Their importance raises the question of whether and how they could address the contemporary proclamation of the Gospel - at least in the pre-evangelisation phase, when it is necessary to answer the criticism of Christianity in a clear but comprehensible way. This study examines Chesterton's influence on Lewis, their common sacramental vision of the world, and 
the principles of their realism. The presentation of such a worldview in their writings appealed to many readers and encouraged other conversions. Therefore, this study shows that Chesterton and Lewis present a convincing form of realism - the so-called sacramental realism which provides important principles for new apologetics of Christianity as preparation for evangelisation today.

\section{Chesterton's Influence on Lewis}

One can find the probably best-known direct reference of Lewis's tribute to Chesterton in his autobiography Surprised by Joy (1955): 'In reading Chesterton, as in reading MacDonald, I did not know what I was letting myself in for. A young man who wishes to remain a sound Atheist cannot be too careful of his reading."

Lewis was fascinated by Chesterton's presentation of history, which broke his atheistic prejudices and started his religious conversion: 'Then I read Chesterton's Everlasting Man and for the first time saw the whole Christian outline of history set out in a form that seemed to me to make sense. ${ }^{2}$ In addition to this rational influence on his mind, Lewis found in Chesterton - 'the most sensible man alive' - much more:

It was here that I first read a volume of Chesterton's essays. I had never heard of him and had no idea of what he stood for; nor can I quite understand why he made such an immediate conquest of me. It might have been expected that my pessimism, my atheism, and my hatred of sentiment would have made him to me the least congenial of all authors. It would almost seem that Providence, or some 'second cause' of a very obscure kind, quite overrules our previous tastes when it decides to bring two minds together. Liking an author may be as involuntary and improbable as falling in love. I was by now a sufficiently experienced reader to distinguish liking from agreement. I did not need to accept what Chesterton said in order to enjoy it. His humor was of the kind which I like best not 'jokes' imbedded in the page like currants in a cake, still less (what I cannot endure), a general tone of flippancy and jocularity, but the humor

\footnotetext{
1 C. S. Lewis, Surprised by Joy. The Shape of My Early Life (New York: Harcourt, Brace \& World, Inc., 1955), 191.

2 Lewis, Surprised by Joy, 223.
} 
which is not in any way separable from the argument but is rather (as Aristotle would say) the 'bloom' on dialectic itself. The sword glitters not because the swordsman set out to make it glitter but because he is fighting for his life and therefore moving it very quickly. For the critics who think Chesterton frivolous or 'paradoxical' I have to work hard to feel even pity; sympathy is out of the question. Moreover, strange as it may seem, I liked him for his goodness... ${ }^{3}$

These may be the only well-known words that Lewis spoke about Chesterton, but there are many more references to Chesterton in Lewis's works. Thanks to a study by Iain T. Benson, one knows exactly which Chesterton's books Lewis owned and where exactly he mentioned Chesterton: The list contains up to 23 citations. ${ }^{4}$ In addition, Benson stated that Lewis was able to talk to his students and friends about Chesterton's works 'with great interest and at length' and that he 'read most of Chesterton's theological books. ${ }^{5}$ As for the textual critique itself, Benson's research confirms that Lewis was deeply moved and influenced by Chesterton.

The very list of documented quotations from Chesterton does not mean that Lewis did not refer to Chesterton more often and even indirectly without mentioning his name. On the contrary, it is clear that some of Lewis's Christian worldview principles find their correspondence or even foundation in Chesterton. As Gisbert Kranz wrote: 'Not only did Lewis express convictions and ideas which had been expressed by Chesterton; he sometimes expressed these ideas by the same similies, metaphors, and images, or in the same manner which Chesterton used in expressing them. ${ }^{\prime}$

Surprisingly, one of Lewis's best-known arguments for Christianity, his logical evidence of the deity of Jesus Christ, also called the 'trilemma', finds its origins in Chesterton. In his Mere Christianity (1952), Lewis argued that there were only three philosophical ways to approach the person of Jesus: 'Either this man was, and is, the Son of God: or else

Lewis, Surprised by Joy, 190-191.

4 See for the complete list: Iain T. Benson, 'The Influence of the Writings of G. K. Chesterton on C. S. Lewis: The Textual Part,' The Chesterton Review 17, no. 3-4 (1991): 357-367, doi: 10.5840/chesterton1991173/4100.

5 Benson, 'The Influence of the Writings of G. K. Chesterton on C. S. Lewis,' 358, 359.

6 Gisbert Kranz, 'Affinities in Lewis and Chesterton,' The Chesterton Review 17/3-4 (1991): 324, doi: 10.5840/chesterton1991173/497. 
a madman or something worse... Now it seems to me obvious that He was neither a lunatic nor a fiend: and consequently, however strange or terrifying or unlikely it may seem, I have to accept the view that He was and is God. ${ }^{97}$ Similarly, in his Everlasting Man (1925), Chesterton wrote: 'No atheist or blasphemer believes that the author of the Sermon on the Mount was a horrible half-witted imbecile that might be scrawling stars on the walls of a cell... Yet by all analogy we have really to put him there or else in the highest place of all.8 The approach is different, but the logic of the argument is the same. Lewis focused on reason and rational choice, while Chesterton utilised emotional and picturesque vocabulary that appealed to common sense. But they both challenged misunderstandings about Jesus and about the basic personal decision his person carries.

This argument about Jesus is just one of the most striking similarities in Chesterton's and Lewis's thinking. Martin Moynihan offers many other common points: friendship between reason and faith, polemical style, putting their convictions into fictional stories, laughter, and the gift of prophecy. ${ }^{9}$ And one could go on. Still, the observation by Fischer and Derbesy is much more powerful: 'We argue that Lewis received an understanding of the literary Christian's task from G. K. Chesterton, whose profound influence on Lewis shaped the latter's conception of how a Christian should write. ${ }^{10}$

Such a statement deserves attention. By no means is it possible to deny Lewis's originality and the contribution of his apologetics; still, this observation helps to understand that Lewis's apologetics were, in principle, in accordance with Chesterton's apologetics, which in turn were truly orthodox and dated back to early Christianity. If Fischer and Derbesy tell the truth about the influence of Chesterton's literary craft and philosophical framing on Lewis, then one can happily place these

7 C. S. Lewis, Mere Christianity (New York, NY-London-Auckland-Toronto-Pymble: HarperCollins Publishers, Adobe Acrobat eBook Reader, 2009), 52-53.

8 Gilbert Keith Chesterton, The Collected Works. Volume II: St. Francis of Assisi, The Everlasting Man, St. Thomas Aquinas (San Francisco: Ignatius Press, 1986), 335. See also: Benjamin Fischer, Philip C. Derbesy, 'Literary Catholicity: An Alternate Reading of Influence in the Work of C. S. Lewis and G. K. Chesterton,' Religion and the Arts 19 (2015): 393-394, doi: 10.1163/15685292-01904004.

9 Martin Moynihan, 'C. S. Lewis and G. K. Chesterton,' The Chesterton Review 17/3-4, (1991): 402-404, doi: 10.5840/chesterton1991173/4108.

10 Benjamin Fischer, Philip C. Derbesy, 'Literary Catholicity', 392. 
two writers amongst the orthodox apologists for Christianity because, as Chesterton himself said, he discovered nothing new but the old orthodoxy. ${ }^{11}$ Lewis and Chesterton are just two voices of old principles and truths that need to be dusted off once in a while so that their sound can resonate anew with greater power. Therefore, we claim that their apologetics resound with the voice of ancient martyrs and advocates of Christianity and that it is precisely this magical combination of the old truth and the new form that can appeal to contemporary man. It can already be assumed that 'the old truth' is the Christian belief about objective reality, which, however, always points to a deeper transcendent reality. This is visible only through the recognition of a mystery that cannot be discovered by reason alone; something else must be used. This 'something else' already speaks of a new form that is typical for Chesterton and Lewis. Such a symbiosis of old content and new form in their work offers a type of realism that can be called sacramental realism.

\section{Chesterton's and Lewis's Sacramentalism}

One of the first truths that these masters of new apologetics taught us is a sacramental perception of the world. It is a view by which one looks at familiar things with astonishment, with a hint of an unknown mystery about the complex fullness of existence. At the same time, it never escapes from the reality of sensuality and concreteness no matter how painful, incomplete, and vague it is. To describe Chesterton's and Lewis's understanding of reality, Ian Boyd coined the term 'sacramental mysticism'. Thus, he emphasised that 'the exterior of material reality is a diguise for its inner spiritual splendour. ${ }^{12}$

An example of such sacramental mysticism can be found in Chesterton's novel The Man Who Was Thursday: A Nightmare (1908). Here, Chesterton played with reality as a disguise for inner spiritual splendour in the person of his main character, the mysterious Sunday. Those who see Sunday tremble: 'That's Sunday. He is perhaps five

11 See Chesterton's introduction to his Orthodoxy. In: The Collected Works I: Heretics; Orthodoxy; The Blatchford Controversies (San Francisco: Ignatius Press, 1986), 211215. Hereafter $C W$, I.

12 Ian Boyd, 'Chesterton and C. S. Lewis,' The Chesterton Review 17/3-4 (1991): 303, doi: 10.5840/chesterton1991173/495. 
hundred miles off, but the fear of him is on all of them, like the finger of God.' ${ }^{13}$ However, they are scared only until they see his face:

And then the queer thing happened. I had seen his back from the street, as he sat in the balcony. Then I entered the hotel, and coming round the other side of him, saw his face in the sunlight. His face frightened me, as it did every one; but not because it was brutal, not because it was evil. On the contrary, it frightened me because it was so beautiful, because it was so $\operatorname{good} .^{14}$

Such a discovery offers the interpretation that Sunday is in reality God Himself. Thus, Chesterton depicts God allegorically as a person visible only from behind, disguised as Nature and unrecongnizable because of the complex, incomprehensible passage of time. Such a mysterious person causes fear, but when people see His true face, the fear disappears. ${ }^{15}$ Still, it is the one and the same Sunday. Thus it turns out that for Chesterton, as well as for Lewis, this world is not only a 'resemblance', a 'mask' of eternal reality, but also its real presence - despite the fact that we do not perceive it that way and do not feel it. As Boyd emphasised, both writers leaned towards the original meaning of the word sacramental: 'As Chesterton explained in his book about St. Thomas, when material things deceive, they deceive not by being ephemeral and transitory, but "by being far more real" than they appear to be.' ${ }^{16}$

Chesterton emphasised that the supernatural is truly present in this world, that it forms the basis of what is meant by 'nature', and that without it, all things lose their substance. As he wrote in his Heretics (1905): 'Take away the supernatural, and what remains is the unnatural. ${ }^{17}$ It is in this sense that he could paradoxically say about the supernatural reality: 'The supernatural is natural, in the sense of normal.. ${ }^{18}$ Without

13 Gilbert Keith Chesterton, The Collected Works VI: The Club of Queer Trades, The Napoleon of Notting Hill, The Man Who Was Thursday (San Francisco: Ignatius Press, 1991), 587. Hereafter $C W$, VI.

$14 \quad C W V I, 621$.

15 See Maisie Ward, Gilbert Keith Chesterton (New York: Sheed \& Ward, 1943), 193.

16 Ian Boyd, 'Chesterton and C. S. Lewis,' 304.

$17 \quad C W I, 88$.

18 Gilbert Keith Chesterton, Il soprannaturale è naturale: Scritti per l'Italia, a cura di Marco Antonellini (Genova-Milano: Casa Editrice Marietti, 2012), 110: 'Il soprannaturale è naturale, nel senso di normale.' 
supernatural reality, one cannot say what is natural or normal at all. Boyd confirmed that both writers were convinced about the sacramental presence of the supernatural in the natural so that man could know the true nature of the world.

For both Chesterton and Lewis, Christ is the Sacrament of God, because He is the human temple in which God dwells. For both authors, this mystery of God's presence extends throughout history through the mystery of the Church, a Community of Believers who form the mystical body of Christ. ${ }^{19}$

Boyd saw that Lewis was in accordance with Chesterton in The Allegory of Love (1936), where he presented symbolism and sacramentalism as synonyms. Lewis said: 'The attempt to read "that something else" [the unseen spiritual world] through its sensible imitations, to see the archetype in the copy, is what I mean by symbolism or sacramentalism. ${ }^{20}$ In other words, Lewis reiterated that the reality of this world is a reflection of the mystery that we do not see face to face, but only as if from behind. This world is, however, penetrated by the supernatural, and this fact makes the world extraordinary and holy. As Boyd said, Lewis appropriated typical Chestertonian language and logic regarding the sacramental nature of people:

There are no ordinary people. You have never talked to a mere mortal. Nations, cultures, arts, - these are mortal, and their life is to ours as the life of a gnat... Next to the Blessed Sacrament itself, your neighbour is the holiest object presented to your senses. If he is your Christian neighbour he is holy in almost the same way, for in him also Christ vere latitat - the glorifier and the glorified, Glory Himself, is truly hidden. ${ }^{21}$

The principal mutual agreement between Chesterton and Lewis about the sacramentality of the world was much greater than a slight disagreement about the possibilities of knowing God in it. While Chesterton was overflowing with a more optimistic attitude, with a joy that

19 Ian Boyd, 'Chesterton and C. S. Lewis,' 305.

20 C. S. Lewis, The Allegory of Love. A Study in Medieval Tradition (Oxford-New York, NY: Oxford University Press, 1958), 45.

21 C. S. Lewis, 'The Weight of Glory' (8 June 1942). Available online: http://www .wheelersburg.net/Downloads/Lewis\%20Glory.pdf. 
God can be known in and through created things, Lewis was more pessimistic about external reality and more drawn into the depths of the inner world where God can be found. As Boyd rightly pointed out, the difference in Chesterton's and Lewis's sacramental views was a reflection of the differences in their personalities. Chesterton was more of a Thomist and Lewis was an Augustinian. ${ }^{22}$ Moreover, Boyd perceived that the difference between them stemmed from their denominational worldview, which must be reflected inevitably in their understanding of the grace operating in the world: Chesterton was a Catholic and Lewis was an Anglican. ${ }^{23}$ Boyd's conclusion was, however, optimistic when he said that 'the sacramental ideas that they share form a bridge between the two traditions. ${ }^{24}$

\section{Realism in Chesterton and Lewis}

Together with the principle of sacramentalism, ontological realism is naturally debated in tandem. Chesterton and Lewis could not discuss the presence of the supernatural in the natural if they were not convinced about the objective reality of things and about the possibility of knowing the truth through and in them. The deep-rooted realism of Chesterton and Lewis - in conjunction with their sacramentalism offered an important epistemological consequence, which stood as the second pillar of their inspiring apologetics: that we can know the truth only by broadening our reason with imagination.

As can be seen throughout Chesterton's works, he criticised the kind of people who looked at the world only through logic and strictly limited reason. According to him, they lived in a world of fictional abstractions and not in reality and as such could not find the truth about life. Moreover, Chesterton was convinced that a person who wants to live everyday life only on the principles of logic and neglect common sense cannot be normal. As he wrote in Orthodoxy, man needs a balance between logic and mystery that transcends the world, and he calls this balance mysticism: 'Mysticism keeps men sane. As long as you have mystery you have health; when you destroy mystery you create

22 Ian Boyd, 'Chesterton and C. S. Lewis,' 308.

23 Ian Boyd, 'Chesterton and C. S. Lewis,' 309-310.

24 Ian Boyd, 'Chesterton and C. S. Lewis,' 311. 
morbidity. The ordinary man has always been sane because the ordinary man has always been a mystic. ${ }^{25}$

Such persistence in two worlds - the world of facts and the world to which these facts point - allows a mystic to have a completely different knowledge than a logician despite the apparent contradiction the mystic may encounter during the cognitive process. Because he is aware of the possibility of the mystery that transcends him, the mystic will not reject the a priori apparent contradiction: 'He has always cared more for truth than for consistency. If he saw two truths that seemed to contradict each other, he would take the two truths and the contradiction along with them. ${ }^{26}$ The logician would reject the contradiction because it is illogical and inconsistent. Chesterton, however, convincingly argued that the fact that something is not logical does not inevitably mean that it is not true:

Logic and truth, as a matter of fact, have very little to do with each other. Logic is concerned merely with the fidelity and accuracy with which a certain process is performed, a process which can be performed with any materials, with any assumption. ${ }^{27}$

Truth can be discovered by a different path than the path of logic: 'Briefly, you can only find truth with logic if you have already found truth without it. ${ }^{28}$

But how can man find the truth? How does man change his own mindset so as to accept a claim about the wider reality? How can man accept the fact that logic is not everything? Chesterton suggested that it is possible only if one takes the process of reaching the truth seriously in everyday life - through common sense and by using imagination.

Most men would return to the old ways in faith and morals if they could broaden their minds enough to do so. It is narrowness that chiefly keeps them in the rut of negation. But this enlargement is easily misunderstood because the mind must be enlarged to see the simple things or even to see

\footnotetext{
CW I, 230.

CW I, 230.

27 G. K. Chesterton, In Defense of Sanity. The Best Essays of G. K. Chesterton, selected by Dale Ahlquist, Joseph Pearce, and Aidan Mackey (San Francisco: Ignatius Press, 2011), 89.

28 Chesterton, In Defense of Sanity, 90.
} 
the self-evident things. It needs a sort of stretch of imagination to see the obvious objects against the obvious background, and especially the big objects against the big background. ${ }^{29}$

The call for expanded reason, so similar to the teachings of Pope Benedict XVI, represented for Chesterton a call for common sense, imagination, and intuition. Therefore, when Chesterton compared logicians and poets, he preferred the latter because of the broad and almost infinite horizons of their spirit: 'Poetry is sane because it floats easily in an infinite sea; reason seeks to cross the infinite sea, and so make it finite. ${ }^{50}$ The poet is free to use not only a narrowly defined reason but also other non-logical abilities like imagination, which enable him to encounter new possibilities of cognition, while the logician wants to comprehend everything with his logic: 'And it is his head that splits. ${ }^{31}$

Much could be said about Chesterton's call for imagination, but it is enough to provide only one of his more philosophical quotes, where he explicitly stated how imagination is helpful to logic. In his commentary on Charles Dickens, Chesterton described the role of imagination as organising facts into meaningful order and as a bearer of truth:

A touch of fiction is almost always essential to the real conveying of fact, because fact, as experienced, has a fragmentariness which is bewildering at first hand and quite blinding at second hand. Facts have at least to be sorted into compartments and the proper head and tail given back to each. ${ }^{32}$

It is precisely imagination that helps reason to see properly what can be seen and to classify the facts so that they make sense.

The same could be said about Lewis, who confirmed the significance of imagination along with reason while following Chesterton's logic to the letter. In the not-so-well-known essay, 'Bluspels and Flalansferes: A Semantic Nightmare' (1939), Lewis wrote about apologetics, which

29 Gilbert Keith Chesterton, The Collected Works III: The Catholic Church and Conversion, The Thing: Why I Am a Catholic, The Well and the Shallows, The Way of the Cross - and others (San Francisco: Ignatius Press, 1990), 215.

$30 \quad C W I, 220$.

31 CWI, 220.

32 Gilbert Keith Chesterton, The Collected Works XV: Chesterton on Dickens (San Francisco: Ignatius Press, 1989), 149. 
is a reasoned defence in the first place. However, he argued that before reason can initiate its operation, there has to be some organ at work that presents and classifies the material as meaningful to reason. This role of supplying the facts and the role of their classification according to the degree of meaningfulness belongs to imagination. ${ }^{33}$ Imagination is thus 'the organ of meaning' that takes priority over reason as 'the organ of truth' ${ }^{34}$

Such a close connection between imagination and truth played a crucial role in Lewis's own life and in his conversion to Christianity. As he wrote in the autobiography Surprised by Joy, the beginning of his path to the Christian faith was a 'baptism' of imagination. The process of accepting the world as a meaningful and holy place - where transcendence to eternity is possible - began with the rebirth of his imagination, not of his reason..$^{35}$ As we already know, Lewis was inspired on the path to Christianity by Chesterton and his Everlasting Man, by its Christian presentation of history, which confirmed that Lewis himself was in need of 'the organ of meaning' so as to classify and organise facts into a meaningful whole. The Everlasting Man influenced Lewis's imagination much more than his reason. ${ }^{36}$

Of course, there are no doubts about the irreplaceable role of imagination in the final acceptance of Christianity by Lewis in 1931. Lewis came to believe Christianity after a well known long night conversation with his friends and colleagues J. R. R. Tolkien (1892-1973) and Hugo Dyson (1896-1975). Lewis admired the power of pagan myths, which fascinated him, but he was not able to see the Gospel story in the same light. He understood Christianity more as a set of doctrines than as a story powerful enough to fascinate and delight. In a letter to his friend Arthur Greeves from October 18, 1931, Lewis wrote that he was not able to understand how the two-thousand-year-old story could have had an

33 Michael Ward, 'The Good Serves the Better and Both the Best: C. S. Lewis on Imagination and Reason in Apologetics,' in Imaginative Apologetics. Theology, Philosophy and the Catholic Tradition, ed. Andrew Davison (London: SCM Press, 2011), 60-61.

34 C. S. Lewis, 'Bluspels and Flalansferes: A Semantic Nightmare,' in Selected Literary Essays, ed. Walter Hooper (Cambridge: Cambridge University Press, 1969), 265. See also Ward, 'The Good Serves the Better,' 61-62.

35 Lewis, Surprised by Joy, 181. Also: Ward. 'The Good Serves the Better,' 63.

36 Christopher Derrick, 'Some Personal Angles on Chesterton and Lewis,' in G. K. Chesterton and C. S. Lewis: The Riddle of Joy, eds. Michael H. Macdonald, Andrew A. Tadie (Grand Rapids, MI: William B. Eerdmans Publishing Company, 1989), 5-6. 
impact on any contemporary man. ${ }^{37}$ His two friends, therefore, did not lead a frontal attack on Lewis's rational acceptance of Christianity but rather on the imaginative rebirth of his perception of Christianity as a true myth that can affect everyone because it is full of meaning and purpose.

Lewis's biographer, Alister McGrath, confirmed that Lewis's final conversion was about the meaning of Christianity, not about its truth. ${ }^{38}$ It was Tolkien and his way of thinking about myths that opened Lewis's eyes and helped him to grasp fragments of truth in the stories people memorised and passed down from generation to generation. Thus, the old truth was being inhaled through various images and gave meaning to both the present and the future. McGrath wrote about the imaginative power of the myth according to Tolkien: 'Myths possess an innate capacity to expand the consciousness of their readers, allowing them to transcend themselves. ${ }^{39}$ After such guidance, Lewis was able to bring together everything he had understood, felt, and lived into a great and perhaps shocking, but meaningful conclusion: Christianity tells a true story, 'which makes sense of all the stories that humanity tells about itself. ${ }^{40}$ Tolkien helped Lewis discover the link between reason and imagination in Christianity.

Unsurprisingly, Chesterton offered the same conclusion in The Everlasting Man: 'The rivers of mythology and philosophy run parallel and do not mingle till they meet in the sea of Christendom. ${ }^{41}$ Reason and imagination are two ways through which man seeks the truth, and what a surprise it must be when he finds something that appropriates both without any diminishment:

The Catholic faith is the reconciliation because it is the realisation both of mythology and philosophy. It is a story and in that sense one of a hundred stories; only it is a true story. It is a philosophy and in that sense one of a hundred philosophies; only it is a philosophy that is like life. But above

37 C. S. Lewis, 'Letter to Arthur Greeves, 18 October 1931,' in The Collected Letters of C. S. Lewis I, ed. Walter Hooper (London: HarperCollins, 2000), 976-977. See also: Alister McGrath, C. S. Lewis - A Life: Eccentric Genius, Reluctant Prophet (Carol Stream, IL: Tyndale House Publishers, Inc., ebook, 2013), 322-323.

38 McGrath, C. S. Lewis - A Life, 324.

39 McGrath, C. S. Lewis - A Life, 326.

40 McGrath, C. S. Lewis - A Life, 326.

41 Gilbert Keith Chesterton, The Collected Works II: St. Francis of Assisi, The Everlasting Man, St. Thomas Aquinas (San Francisco: Ignatius Press, 1986), 243. Hereafter CW II. 
all, it is a reconciliation because it is something that can only be called the philosophy of stories. That normal narrative instinct which produced all the fairy tales is something that is neglected by all the philosophies - except one. The Faith is the justification of that popular instinct; the finding of a philosophy for it or the analysis of the philosophy in it. ${ }^{42}$

This quote about how Christianity fulfils the narrative instinct as well as the instinct for truth is the highlight of Chesterton's and Lewis's presentation of Christianity. Their vision of Christianity hit the centre of reality because it reconciled reason and imagination, philosophy, and mythology. Their realism was broader and deeper than the flattened realism of modernity, which limited man to a logical machine, as well as the distorted realism of postmodernism, which made man a part of a story without meaning. The sacramental realism of Chesterton and Lewis offered a complex but meaningful story that satisfies man's desire to live in the Truth forever. In the last part, we will present the meaning of such a vision of Christianity for practical application in pre-evangelisation.

\section{New Apologetics as Pre-evangelisation}

Chesterton and Lewis offered a presentation of Christianity that was rich and unique for their times because it did not neglect man's desire for miracles, for dynamism, for fairy tales, or for stories. These are the categories that influence art and culture even today. This fact is confirmed by the popularity of fantasy sagas (The Lord of the Rings, The Game of Thrones, Harry Potter, The Witcher, etc.) or superhero movies from Marvel and DC. The desire for a powerful story that offers values in the battle between good and evil forces is deeply rooted in man, and it reflects the inner longing for such a story that would at the same time be true.

Therefore, new apologetics is not faced with the question of whether Christianity should be presented with imaginative force. After the ongoing success of Chesterton, Lewis, and many other contemporary apologists who followed their example, it is clear that if apologetics is possible, it must be imaginative. This is the basic premise that corresponds with the situation in which one finds themself today. Although

${ }_{42} \quad C W I I, 378$. 
contemporary man still refers to what science has confirmed or refuted, he spends much more time in virtual reality, where his desire for meaning is hidden. The reason that guides contemporary man hopelessly longs for meaning. Today, one needs to be baptised precisely in the manner Lewis was baptised: to be able to comprehend that he does not yet see everything that is there to be seen; and then, after such a rebirth of imagination, to lead him to examine the meaningfulness and truth of the story he is living in.

That is why imagination is necessary; however, the question remains to what extent. We know that imagination helps reason to expand and open itself for infinity. It awakens wonder and curiosity; it offers a new perspective on old things, and it provides questions that one has not yet asked themself. However, at some point, it may deceive and may lead reason to a path of false meaning. Therefore, baptised imagination must never let go of logic. Baptised imagination cannot be satisfied with offering simply a meaningful vision of reality; it needs to offer a vision that satisfies the instinct for truth as well.

Chesterton and Lewis offered a solution in their own way, which was described as 'sacramental mysticism'. In general, a mystic means a person that lives in a place and time removed from our world, in a different reality that transcends the sensual everyday experience. Thus, it would seem that the mystical experience has something to do only with the other world and nothing with our world. That is not the case with Chesterton and Lewis. Mysticism uncovers the transcendent precisely in and through the ordinary. It does not mean distancing oneself from reality but an immersion into the real reality, which is the supernatural. The mystic never abandons this world. He is always present in it in a more profound way. That is why Chesterton defended poets and their 'mystical imagination' as sane and 'business-like'. ${ }^{43}$ Poets who have their imagination baptised - who have such a mystical imagination - will not run away from reason and logic; exactly the opposite, they will offer a portrait of reality that is both creative and true at the same time. Therefore, new apologetics should follow this pattern: it should be as vivid and eye-opening as the imagination permits while remaining rational and universal thanks to logic.

Finally, a new apologetics should utilise Chesterton's and Lewis's understanding of sacramentalism as 'symbolism' because their

43 See $C W I, 219$. 
sacramental vision includes both the philosophical-theological content of the eternal truth as well as a narrative form that actualises the meaning of truth for the contemporary man. The sacred symbol is much richer than the word of doctrine because it offers a reality that is deeper and even more attractive than the encyclopedic definition of truth. The symbol is able to awaken indifferent people, to engage them, to offer them a meaning that reignites their desire to know the truth hidden behind it. At the same time, the sacred symbol is not lost in imagery and imaginativeness because it adheres to God's truth, which is in truth Himself. The sacred symbol corresponds to the longing of the human heart, which desires to wander and discover. At the same time, the symbol does not simply remain at the level of wandering, but it holds on to the vision of its goal, of its home, where it finds the truth about itself. Such an understanding of sacramentalism is like life itself: it desires adventure as well to reach its destination.

The value of Chesterton's and Lewis's apologetics both in the past and in the present is indisputable. The extent to which the principles of their unique sacramental realism can offer new apologetics and how new apologetics can be practically developed from these principles remains to be answered. However, it is not the aim of this study to address the practical development of their apologetics. This study set for itself the task of laying the theoretical foundations on which further study can be built while researching practical applications.

\section{Conclusion}

This study offered a presentation of Chesterton's and Lewis's sacramental realism and its meaning for contemporary pre-evangelisation. It has demonstrated the extent to which Lewis was influenced by Chesterton and his work. Lewis's apologetics is thus fundamentally identical to Chesterton's, and both brought a fresh new perspective on the Christian tradition. Their works confirmed the sacramental perception of the world, where the supernatural is present in the natural. In order to perceive it, one needs the baptism of imagination, through which the meaning of reality is presented to reason. Imagination is thus an essential part of apologetics that can appeal to contemporary man. It is this new apologetics that can serve as a suitable preparation for the proclamation of the Gospel because it presents Christianity as a place where the two main instincts for a story and for the truth are intertwined. 
The testimony of these two converts is the best model of pre-evangelisation: a story of sacramental realism in practice. The symbols, images, and vitality of Christianity did not leave Chesterton and Lewis alone until they realised that they had not yet seen everything meaningful in the world. Awakened, they began to look for what would satisfy human desires and instincts fully. Like St. Peter, who was drowning in the sea, they began to look for a new certainty upon which to build their lives. And they saw Jesus as a real person, not a doctrine. They entrusted their lives to Him since everything indicated that a story with Him at its centre would be true and meaningful. From that moment on, everything started to fit together, and they began to see His footprints and His symbols everywhere: the whole world made sense. Their apologetics is a testimony and personal guidance for those who are drowning like them. Chesterton and Lewis were not afraid to ask questions nor to receive them. Their apologetics are, therefore, more about listening than talking; more about fixing eyes upon the mystery than explaining the incomprehensible. This new apologetics is patient and does not persuade with force: it waits until one asks the question because, from the very beginning, it has been entrusted to be prepared to 'give the reason for the hope' that is in us (1 $\mathrm{Pt} 3: 15)$.

Theological Faculty Catholic University in Ruzomberok Hlavná 89 04001 Košice, Slovakia E-mail: pavol.hrabovecky@ku.sk 